\title{
'We are like the Poles': on the ambiguous labour market position of young Icelanders
}

Margrét Einarsdóttir, Researcher, Faculty of Social and Human Sciences, University of Iceland

Jónína Einarsdóttir, Professor, Faculty of Social and Human Sciences, University of Iceland

Guðbjörg Linda Rafnsdóttir, Professor, Faculty of Social and Human

Sciences, University of Iceland

\begin{abstract}
Paid work is quite common amongst young people under the age of 18 in the Western world, although most undertake flexible part-time work. Nevertheless, studies on their labour market position are rare. The aim of this article is to examine the labour market position of young people in Iceland, a high-income Nordic country. We ask about: (i) young people's general labour market rights regarding payslips and formal work contracts; (ii) their special labour market rights, safeguarded by child labour laws, in relation to rest periods, working hours, the prevalence of injuries and the consequent absence from work, and; (iii) the young persons' own perceptions of their labour market position. The study is based on mixed methods: a survey $(\mathrm{N}=952)$ and group interviews $(\mathrm{N}$ $=42$ ) with 13-17-year-olds. The research reveals that the labour market position of young people is characterised by ambiguity. While their general rights to employment and decent pay are recognised to some extent, their work often violates child labour laws and accidents do occur. Young people commonly perceive their labour market position as weak. Their position in society, on the other hand, allows them to quit when confronted with an adverse work environment or if the work interferes with other duties. To conclude, education
\end{abstract}

\author{
Icelandic Review of Politics and Administration Vol 11, Issue 2 (269-288) \\ (C) 2015 Contact: Margrét Einarsdóttir, margrei@hi.is \\ Article first published online December 17th 2015 on http://www.irpa.is \\ Publisher: Institute of Public Administration and Politics, Gimli, Sæmundargötu 1, 101 Reykjavík, Iceland \\ Stjórnmál \& stjórnsýsla 2. tbl. 11. árg. 2015 (269-288) Fræđigreinar \\ (C) 2015 Tengiliður: Margrét Einarsdóttir, margrei@hi.is \\ Vefbirting 17. desember 2015 - Birtist á vefnum http://www.irpa.is \\ Útgefandi: Stofnun stjórnsýslufræđa og stjórnmála, Gimli, Sæmundargötu 1, 101 Reykjavík \\ DOI: http://dx.doi.org/10.13177/irpa.a.2015.11.2.8 \\ This work is licensed under a Creative Commons Attribution 3.0 License.
}


on occupational health and safety (OHS) and additional research on their labour market position are needed.

Keywords: Youth work; labour market position; labour market rights; child labour policy; high-income countries.

\section{Introduction}

Undertaking paid work is a common practice of young people under the age of 18 living in high-income countries (e.g. in Mizen, Pole, \& Bolton 2001b; Price \& McDonald 2011). This might come as a surprise, especially considering that since the $19^{\text {th }}$ century child work has been regulated through particular labour laws in most of these countries (Dahlén 2007b). Nowadays, the minimum age convention of the International Labour Organisation (ILO) no. 138 from 1973 leads the child labour policy worldwide, including the European Union's (EU) and the Icelandic regulations on the matter. The main position of the ILO convention is that children in compulsory education should not work. Due to several exemptions from the main rule, in practice children are allowed to undertake work from the age of 13 , albeit within restricted working conditions. Also, the convention stipulates some restrictions concerning the working conditions of teenagers, aged 16-17. The purpose of those restrictions is to protect children from work injuries and other occupational illnesses (Dahlén 2007a; ILO Minimum Age Convention no. 138/1973).

The international child labour policy is based on the modern construction of childhood which places young people within the sphere of education but outside the sphere of work and production (Dahlén 2007b). Qvortrup (1995) argues that this construction has deprived children in high-income counties of economic power. Also, due to the full-time school-attendance of young people, their work is typically parttime and flexible (Liebel 2004), characteristics that have been associated with the weak labour market position of other social groups such as immigrants, disabled people and to some extent women (Grint 2004). Further contributing to the weak labour market position of children could be the fact that child labour laws do not address the rights to employment and decent pay, important features of the general labour market rights of adults (Hanson \& Vandaele 2003). In addition, because of the strong connection between the ILO and trade unions, and as the ILO sets the minimum age for work around the age of 16 , the unions usually limit their membership to those who have reached that age (Myrstad, 1999).

Hanson and Vandaele (2003) propose that the participation provisions of the United Nations Convention on the Rights of the Child (UNCRC), which guarantee young people's right to political participation ${ }^{1}$, should also guarantee their economic participation, and, consequently, their general labour market rights to employment and to decent pay. Also, studies show that young people commonly stress that they should hold those rights (Leonard 2004; Liebel 2004). Nevertheless, research on the implementation of these rights and on the specifics of the labour market position among young people 
in high-income countries is rare. Yet, studies from North America that examine the occupational health and safety of young workers show that perceived powerlessness may hinder them from voicing their concerns about unsafe working conditions (Breslin Polzer, MacEachen, Morrongiello \& Shannon 2007; Tucker \& Turner 2013; Zakocs, Runyan, Schulman, Dunn, \& Evensen 1998). Identically, Australian research on the industrial citizenship of young workers indicates that powerlessness may cause the young workers to downplay work injuries (McDonald, Bailey, Price \& Pini 2012).

The aim of this article is to analyse the labour market position of young people aged 13-17 in Iceland in relation to their labour market rights. The focus is on: (i) whether their general labour market rights are recognised with regards to receiving a mandatory payslip and having a formal work contract; (ii) whether their special labour market rights, safeguarded by child labour laws, are secured in relation to rest periods, evening and night work and working hours, as well as the prevalence of work injuries amongst the age-group and consequent length of absences from work, and; (iii) the young persons' own perceptions of their labour market rights and position. In this article, and in line with the Icelandic regulations on child labour, individuals under the age of 18 as a whole are termed 'young people', those still in compulsory education as 'children' (usually younger than 16), and those who have completed compulsory education yet have not reached the age of 18 as 'teenagers' (16-17-year-olds) (“Act on Working Environment, Health and Safety in Workplaces," no. 46/1980).

In the following, the labour market rights of young people will be elaborated, as well as the background information on child and teenage work in Iceland. Then, the methods applied and the findings of the research will be presented. Finally, the young workers' ambiguous labour market position will be discussed and conclusions summarised.

\section{The labour market rights of young people}

Child labour laws can be traced back to the $19^{\text {th }}$ century and the formulation of the modern construction of childhood. In the wake of industrialisation, the ideas of what it is to be a child and what kind of activities are proper for the young to undertake changed; increasingly, children were seen as in some way peculiar and innocent by nature compared to adults, and it was believed that this innocent nature could be spoiled by improper situations, including by the young people holding adult responsibilities such as work. Consequently, the young people needed to be protected from such situations (Cunningham 2005; James, Jenks \& Prout 1998). To begin with those ideas were heavily debated, but in most European countries they were standardised in legislation on compulsory education and child labour before the end of the $19^{\text {th }}$ century (Dahlén 2007b; Hendrick 1997). Later the ideas were universalised in the minimum age conventions of the ILO, as well as in the UNCRC (Dahlén 2007b).

At the present time, the ILO's minimum age convention no. 138 from 1973 sets the standard for the child labour policy worldwide, including the standard for the EU regulation on the matter (Dahlén 2007b; EU Council Directive 94/33/EC on the protection of young people at work, no. 31994L0033/1994). The EU regulation has 
been further adapted to national legislation, inter alia to the national legislation of all the Nordic countries, Iceland included (Rafnsdóttir 1999). The ILO convention affirms that the minimum age for admission to employment or work 'shall not be less than the age of completion of compulsory schooling and, in any case, shall not be less than 15 years' (ILO Minimum Age Convetion, no. 138/1973). In practice, child labour laws are more complicated. Several exemptions are made from their main rule, including that children are allowed to undertake work from the age of 13 within severely restricted working conditions. The legislation allows teenagers at 16-17 years of age to work, but stipulates some restrictions concerning their working conditions (Dahlén 2007a).

In general, the child labour laws stipulate that children and teenagers should not engage in work likely to harm them physically and mentally, and the laws include any type of employment or work (ILO Minimum Age Convention, no. 138/1973, article 3). ${ }^{2}$ In more particular, the EU directive (94/22/EC) stipulates that children and teenagers should have a minimum rest period of two days each week (article 10), ${ }^{3}$ should not undertake evening and night work (article 9), ${ }^{4}$ and that the working time of children should be limited to 'two hours in a school day and 12 hours a week in term-time', and 'seven hours a day and 35 hours a week for work performed when school is not in session (e.g. summer vacation)' (article 8). ${ }^{5}$ In addition, the directive gives an accurate description of prohibited working conditions regarding machines and devices, chemicals, heat etc. The ILO convention is the point of reference for the stipulation on child labour in the UNCRC (article 32). Based on the link between these two conventions and the EU directive, it can be argued that the provisions on child labour laws concerning restricted working conditions guarantee young people between the ages of 13 and 17 special labour market rights regarding occupational health and safety protection.

Studies show that children and teenagers in high-income societies do commonly undertake paid work. For example, a Scottish study from 2005 revealed that 38\% of Scottish pupils, aged 14-17, held a job at the time of the study (Howieson, McKechnie \& Semple 2006), and research from Canada showed that $62 \%$ of $15-17$-year-olds in Alberta were in employment in 2011 to 2012 (Barnetson 2013). Nevertheless, due to the young people's school attendance their work is usually part-time, and they commonly move in and out of work (Liebel 2004; Mortimer 2003). Also, research shows that child labour laws in high-income societies are commonly breached (McKechnie \& Hobbs 1999; Runyan et al. 2007), and that young Western workers suffer work injuries and other occupational illnesses, in some instances with serious long-time implications (Einarsdóttir, Rafnsdóttir \& Einarsdóttir, 2014; Kines, Framke, Salmi \& Bengtsen 2013).

This empirical evidence has prompted child work researchers to doubt whether the current child labour policy is in the best interest of young workers, although they propose different reactions to its deficiencies (e.g. Gasson, Calder, Diorio, Smith \& Stigter 2014; Leonard 2004; McKechnie \& Hobbs 1999). Thus, Gasson et al. (2014) wonder whether other countries should follow the example of New Zealand, one of the few high-income countries which does not stipulate a minimum age for employment, where- 
as both Leonard (2004) and Hanson and Vandaele (2003) suggest that more emphasis should be placed on securing young people with the general labour market rights to employment and decent pay, usually only connected to adults. The suggestion is grounded on research which shows that young people, whether in affluent or economically deprived societies, often want and/or need the income they gain from their work, and that they commonly stress those general labour market rights (Einarsdóttir 2013; Leonard 2004; Woodhead 1999).

Iceland is an interesting platform from which to study young people's labour market position and the question of how to secure the interests of young people at work. In the late 1990s, the country adopted the EU regulations on child labour, and paid work of children and teenagers became regulated similarly to that of other European countries (Eydal, Rafnsdóttir \& Einarsdóttir 2009). Thus, Iceland is a high-income society which has adapted its legislation to the modern construction of a work-free childhood. Nevertheless, a positive attitude towards child and teenage work has prevailed in the country (Einarsdóttir 2014; Ólöf Garðarsdóttir 1997a). That attitude, as well as the country's Nordic tradition of strong trade unions and expertise in the field of occupational health and safety (OSH), might facilitate the age group's general labour market rights, and consequently, strengthen its labour market position.

\section{Child and teenage work in Iceland}

Like other Nordic countries, Iceland prospered in the $20^{\text {th }}$ century and has been among the most affluent societies of the world during the last decades (Ólafsson 2012). Also, in the Nordic tradition, Iceland has a strong labour culture and welfare system, the rights of wage-earners are comparatively well secured and the position of trade unions strong (Aðalsteinsson 2006). Nevertheless, Iceland stands out with regards to the Nordic characteristics to some extent. Firstly, labour market participation in general is exceptionally high, even within the Nordic context, at 86\% in 2008 (Stefánsson 2012). Secondly, in some aspects the welfare system is weaker than in the other Nordic counties, and Icelanders have had to work more than their neighbours to secure their standard of living (Ólafsson 2012). Also, a positive attitude towards young people's work has prevailed in the country, and there is a stronger tradition of children and teenagers undertaking paid work in the summer than in the other Nordic countries (Einarsdóttir 2014; Garðarsdóttir 1997a; Rafnsdóttir 1999). The participation of young Icelanders in term-time work is more in line with their Nordic counterparts, although the length of the Icelandic working week is longer (Guðmundsdóttir, Sigfússon, Kristjánsson, Pálsdóttir \& Sigfúsdóttir 2010; Rafnsdóttir 1999). In 2009 14.5\% of Icelandic term-time workers worked 15 hours or more a week as compared to between 3.4\% and $8.1 \%$ of term-time workers in the other Nordic countries (Guðmundsdóttir et al. 2010). The summer work tradition in Iceland has been maintained by a long summer vacation in schools, as well as by special summer work projects such as the Icelandic work-schools (Garðarsdóttir 1997a, 2009).

Considering the positive attitude towards child and teenage work in Iceland, the 
adaption of Icelandic legislation to the EU regulations on the matter at the end of the 1990s was debated in the Icelandic Parliament. As such, the Minister of Social and Labour Market Affairs declared that he was strongly against the regulations and regarded them as a pathway to idleness (Eydal et al. 2009). Nevertheless, Parliament passed the laws, and simultaneously the summer vacation within the compulsory education system was shortened from three months to approximately 10 weeks (Eydal et al. 2009; Pálsdóttir 2012). In other words, Iceland took a step towards the construction of a work-free childhood (Einarsdóttir 2014; Garðarsdóttir 1997a).

\section{Methods}

The research is classified as mixed methods research within the approach of research with children. Considering that the research questions gave rise to both quantitative and qualitative methods, the approach of mixed methods research was applied (Johnson \& Onwuegbuzie 2004). Both types of data were collected concurrently and their mixing applied in the final stages of analysing the findings and discussing the research (Creswell \& Clark 2007). Child centred research was applied in order to facilitate the recognition of children and teenagers as social agents worthy of study in their own right, as well as to facilitate findings that represent the young people's own understanding of their lives (Christensen \& James 2008).

The quantitative part of the research constituted a survey on child and teenage work. Together the sample included 2,000 Icelanders, aged 13-17, randomly selected from the Registers Iceland. In total, 952 young people responded, giving a response rate of $48.8 \%$. The design of the survey was based on the design of the research of the Nordic Administrations of Occupational Safety and Health on paid work of 13-17-year-old people in the Nordic countries, conducted during the winter of 1997-1998 (Rafnsdóttir 1999). In order to meet the requirement set forth within the approach of research with children of involving young people in the research (Grover 2004), a group of ten young people was asked to consult on the draft of the questionnaire. They made a number of useful comments to some of the questions, which were subsequently taken into consideration in the final design of the questionnaire. The data was analysed using SPSS software. A Chi-square test was used to test statistical significance and $95 \%$ confidence intervals (CI) applied. Significant association is marked by *.

The qualitative part of the research constituted group interviews. In total, 42 young people aged 13-17, of both genders, all residents of Iceland who had at least some experience of paid work, participated in 14 interviews. In the capital area snowball sampling was used to recruit the participants. Outside the capital area, the school authorities helped with the identification of participants for the interview groups.

The purpose of the group interviews was to explore child and teenage work from the point of view of young people in general. Therefore, young Icelanders with diverse work experience were included in the research, as were young people of both genders, those enrolled in compulsory education as well as in secondary education, those attending school and those not, and those from the capital area as well as from the countryside. ${ }^{6}$ 
Most of the participants had experienced various kinds of jobs. None had no work experience at all, only one had experienced just one type of job (a work-school job), and most had experience of both formal and informal work. In addition to informal work such as baby-sitting and/or work-school jobs, the majority had experience of work in the formal labour market, most commonly in the retail sector.

The interview groups were relatively small, between two and five young people participated in each, and the participants in each group knew each other beforehand. Such small groupings of friends and/or acquaintances have been identified as suitable when interviewing young people (Hill 2006; Mayall 2000). Interviewing small groups of friends contradicts focus groups, the most common form of group interviews in social research with adults, as focus groups are usually constituted of several participants (seven to ten) who are not familiar with each other (Hill 2006; Mayall 2000; Punch 2002). One argument for applying group interviews in research with young people is that unequal power-relations between adult interviewer and young interviewee may hinder an easy-going conversation in a one-to-one interview while a group of counterparts can advance the conversation (James et al. 1998; Punch 2002). Interviewing a small group of friends may also be more fruitful than interviewing a big group of strangers as friendship between the group members can thwart shyness common among young people (Hill 2006; Mayall 2000). The participants were each given a pseudonym to guarantee anonymity.

The research was approved by the Ethical Committee of the Faculty of Social Sciences, University of Iceland (the $18^{\text {th }}$ of October 2007). It was conducted during the peak of the 2000s economic boom in Iceland, and inquired into, on the one hand, paid work during the summer of 2007, and, on the other hand, term-time work during school-year 2007-2008.

\section{Quantitative findings}

Almost all the respondents of the survey reported being in school during school-year $2007-2008$, or $98.1 \%$, and the vast majority, $90.1 \%$, had experience of paid work.

Table 1. Percentage (\%) in summer work, the most common summer job, termtime work, and the most common term-time job, by age and gender

\begin{tabular}{|c|c|c|c|c|c|}
\hline & \multicolumn{2}{|c|}{ Gender } & \multicolumn{2}{|c|}{ Age } & \multirow[t]{2}{*}{ Total } \\
\hline & Girls & Boys & Aged 13-15 & Aged 16-17 & \\
\hline Summer work ${ }^{\text {a) }}$ & $82.5 \%$ & $84.8 \%$ & $76.1 \%$ & $97.3 \%$ & $83.5 \%$ \\
\hline Work school job ${ }^{\text {b) }}$ & $37.1 \%$ & $40.7 \%$ & $50.5 \%$ & $21.6 \%$ & $38.6 \%$ \\
\hline Term-time work ${ }^{c}$ & $55.5 \%$ & $40.4 \%$ & $39.1 \%$ & $67.9 \%$ & $49.0 \%$ \\
\hline Retail job ${ }^{d)}$ & $56.4 \%$ & $39.2 \%$ & $48.1 \%$ & $52.8 \%$ & $50.4 \%$ \\
\hline
\end{tabular}


Table 1 shows that $49 \%$ of the respondents reported participating in paid term-time work. The girls were more likely to undertake such work than the boys, and the older pupils than the younger ones. Half of the term-time workers reported holding a termtime job in the retail sector, the girls more often than the boys. In total, $83.5 \%$ of the respondents worked during the summer of 2007, almost all of those aged 16-17 and more than three quarters of those aged 13-15. The most common summer-job was a job in the work-schools, the special Icelandic summer work projects run by most municipalities in Iceland (Garðarsdóttir 1997a). In total 38.9\% of the summer workers held a work-school job, the younger summer workers were more likely to do so than the older ones. In addition to the most common summer and term-time jobs, the young workers took on various kinds of jobs, as has been discussed in more detail elsewhere (Einarsdóttir 2008, 2014).

Those who reported participation in term-time work were asked if they had received a payslip, if they had had a formal work-contract, and if the work breached certain provisions of the Icelandic child labour laws.

Table 2. Percentage (\%) receiving a payslip, by age and gender

\begin{tabular}{|c|c|c|c|c|c|}
\hline & \multicolumn{2}{|c|}{ Gender } & \multicolumn{2}{|c|}{ Age } & \multirow[t]{2}{*}{ Total } \\
\hline & Girls & Boys & Aged 13-15 & Aged 16-17 & \\
\hline Received payslip & 79.2 & 82.5 & 71.1 & 90.9 & 80.4 \\
\hline
\end{tabular}

Gender: $\chi 2(1, \mathrm{~N}=397)=0.60$. Age* $\chi 2(1, \mathrm{~N}=397)=24.48$.

Table 2 demonstrates that the vast majority, or around four fifths, received a payslip. However, the table does show a significant age difference in receiving a payslip. The younger workers were less likely to receive one than the older workers. It does, however, not show a significant gender difference.

Table 3. Percentage (\%) having a formal contract, by age and gender

\begin{tabular}{|c|c|c|c|c|c|}
\hline & \multicolumn{2}{|c|}{ Gender } & \multicolumn{2}{|c|}{ Age } & \multirow[t]{2}{*}{ Total } \\
\hline & Girls & Boys & Aged 13-15 & Aged 16-17 & \\
\hline Had contract & 22.3 & 29.9 & 20.8 & 29.7 & 24.9 \\
\hline Did not know & 19.6 & 17.5 & 21.2 & 16.2 & 18.9 \\
\hline
\end{tabular}

Gender: $\chi 2(2, \mathrm{~N}=397)=2.76$. Age: $\chi 2(2, \mathrm{~N}=397)=4,78$.

Table 3 illustrates the percentage of young workers who had a formal work contract, and shows that only a quarter had one. In addition, the table shows that nearly a fifth of the young people did not know whether they had a contract or not. The findings do not reveal any gender or age difference regarding having a contract. 
The breaches of the following provisions of the Icelandic child labour laws were investigated in the survey: working excessive hours; undertaking evening and night work; and being given a rest period of two days per week (see "Act on Working Environment, Health and Safety in Workplaces," no. 46/1980). Child labour laws distinguish between children (those still in compulsory education) and teenagers (those who have finished compulsory education but not yet reached the age of 18). The regulation of the work of these two age-groups differs both regarding the working hours and the evening and night work that are allowed as illustrated in Table 3. As weekend work during term-time hinders school age workers from having their minimum two-day rest period, such work is used as an indicator of breaches of the rest-period-provision.

Table 4. Percentage (\%) of the work breaching provisions of child labour law always, often or occasionally, by age and gender

\begin{tabular}{|c|c|c|c|c|c|c|}
\hline & \multicolumn{3}{|c|}{ Aged 13-15 } & \multicolumn{3}{|c|}{ Aged 16-17 } \\
\hline & Girls & Boys & Total & Girls & Boys & Total \\
\hline \multicolumn{7}{|l|}{ Rest period of two days a week ${ }^{a)}$} \\
\hline work on weekends & 83.7 & 68.0 & 78.2 & 83.3 & 90.9 & 85.9 \\
\hline \multicolumn{7}{|l|}{ Not evening and night work ${ }^{\text {b) }}$} \\
\hline work between 20:00 and 06:00 & 45.8 & 45.2 & 45.7 & --- & --- & --- \\
\hline work between $22: 00$ and $06: 00$ & --- & --- & --- & 21.5 & 41.7 & 28.4 \\
\hline \multicolumn{7}{|l|}{ Not intensive work ${ }^{c)}$} \\
\hline$>12$ hours a week & 21.3 & 22.4 & 21.6 & --- & --- & --- \\
\hline$>40$ hours a week & --- & --- & --- & 0.0 & 0.0 & 0.0 \\
\hline
\end{tabular}

a) Aged $13-15^{*}: \chi 2(1, \mathrm{n}=216)=7.08$. Aged $16-17: \chi 2(1, \mathrm{n}=192)=2.06$.

b) Aged 13-15: $\chi 2(1, \mathrm{n}=138)=.004$. Aged $16-17 *: \chi 2(1, \mathrm{n}=141)=6.33$.

c) Aged 13-15: $\chi 2(1, \mathrm{n}=194)=.03$.

Table 4 reveals the commonality of the term-time workers reporting breaches of the Icelandic child labour laws. The provision of a rest period of two days a week is most commonly violated; the vast majority of the young workers reported working either only at weekends, or both on weekdays and weekends during term-time. The breach of the stipulated rest period was significantly more common among the 13-15-year-old girls than among their male counterparts.

Reports of other types of breaches were also common: some $45.7 \%$ of the 13-15-year-olds worked always, sometimes, or occasionally between 20:00 in the evening and 06:00 in the early morning, and $28.4 \%$ of the 16-17-year-olds worked between 22:00 and 06:00. In the older age-group, these kinds of violations were more common among the boys than the girls.

Furthermore, $21.6 \%$ of the younger group claimed to work more than the allowed 12 hours per week during term-time. Notably, the older age-group is allowed to work 40 hours a week during term-time, so it should come as no surprise that the term-time work 
of that age-group hardly ever contravenes the law regarding excessive working hours. No gender differences appeared regarding excessive hours.

Table 5. Percentage (\%) of young workers having had at least one accident at work, by age and gender

\begin{tabular}{|c|c|c|c|c|c|}
\hline & \multicolumn{2}{|c|}{ Gender } & \multicolumn{2}{|c|}{ Age } & \multirow[t]{2}{*}{ Total } \\
\hline & Girls & Boys & Aged 13-15 & Aged 16-17 & \\
\hline No accident & 80.8 & 75.9 & 81.9 & 73.6 & 78.7 \\
\hline One accident & 12.3 & 11.3 & 11.4 & 12.5 & 11.9 \\
\hline More than one accident & 6.9 & 12.8 & 6.7 & 13.8 & 9.5 \\
\hline
\end{tabular}

Gender $* \chi 2(2, \mathrm{~N}=792)=7.70$. Age $*: \chi 2(2, \mathrm{~N}=792)=12.10$.

Table 5 illustrates that around one fifth of the young workers had had at least one accident at work. The table shows a significant age as well as gender difference. Those aged 16-17 were more likely to have had an accident at work than those aged 13-15, and the boys were more likely to have been injured at work than the girls. Also, the boys were more likely than the girls to have been injured more than once.

Table 6. Percentage (\%) having no, one, or more than one week's absence because of work injury, by age and gender

\begin{tabular}{|c|c|c|c|c|c|}
\hline & \multicolumn{2}{|c|}{ Gender } & \multicolumn{2}{|c|}{ Age } & \multirow[t]{2}{*}{ Total } \\
\hline & Girls & Boys & Aged 13-15 & Aged 16-17 & \\
\hline No absence & 69.4 & 59.5 & 65.1 & 63.9 & 64.9 \\
\hline One week or less & 27.1 & 32.1 & 25.6 & 33.7 & 29.8 \\
\hline More than one week & 3.5 & 8.3 & 9.3 & 2.4 & 5.4 \\
\hline
\end{tabular}

Gender: $\chi 2(2, \mathrm{~N}=169)=2.66$. Age: $\chi 2(2, \mathrm{~N}=169)=4.35$.

As Table 6 shows, a relatively large group, on average one third of the young workers, had to have up to one week off from work because of work injuries. In addition, $5.4 \%$ had such a serious work accident that they had more than a week's absence from work because of the injuries. Neither age nor gender difference appears regarding the absences.

\section{Qualitative findings}

In the group-interviews the understanding and experience of the labour market position of young people were discussed. The discussion touched upon factors regarding their special labour market rights, their general labour market rights, as well as upon young people's perception of their labour market position as subordinates. 


\section{STJÓRNMÁL $\&$ \\ STJÓRNSÝSLA}

\subsection{Special labour market rights}

The qualitative findings corroborate the quantitative findings regarding Icelandic child labour legislation often being breached. The most common violations of the legislation that surfaced in the group-interviews were related to the regulation of the length of the working week and to the rest period of two days per week. This is reflected in the answer of Ásbjörn, who had recently turned 14 years of age:

Asbjörn: I work every Monday and every other weekend.

Interviewer: Every Monday all day long, then?

Asbjörn: Four to eleven [pm].

Interviewer: Wait a minute, four to eleven, that accounts for seven hours, and how much do you work during weekends?

Ásbjörn: Let's see, last Saturday I worked from one in the afternoon until eleven at night, but usually I work four to eleven or nine to four.

Ásbjörn's regular work schedule amounted to 21 hours every other week, or nine hours over the limit set by the legislator, and seven hours the other weeks, or five hours under the 12 hours limit. On average, his regular schedule included at least 14 hours of work per week, but his average working week was somewhat higher as he reported often taking extra shifts. In addition, his fortnightly working schedule meant that every other week his work also violated the stipulation on the two day rest period. Ásbjörn's work additionally violated the stipulation on evening and night work as he worked until eleven o'clock at night every Monday, as well as every fourth weekend.

Ásbjörn was not the only term-time worker participating in the group interviews to hold down a fortnightly working schedule; a biweekly rota was a common practice for the term-time workers in the retail sector. Such a rota means that every other week the work of the young worker usually breaches both the stipulation on the length of the working week and that of the two day rest period. The group interviews revealed more instances of breaches of the prohibition of evening and night work, though they were not as prominent as the breaches regarding the length of the working week and the rest period.

The majority of the young people who participated in the group-interviews was aware of the existence of the Icelandic child labour laws, or at least aware that the work of children and teenagers is differently regulated than the work of adults. However, the findings reveal that most were not familiar with the content of the laws. This lack of knowledge surfaced in responses like: 'Which kind of work are [we] allowed to undertake, are we not allowed to undertake most kinds of work?', and 'I think, we can work six hours [per day], not more [during term-time]'. The latter response was from a pupil in compulsory education, and, to recall, the law states that that age-group is not allowed to work more than two hours per day during term-time. Also, the participants 
frequently confused child labour laws with other work-related agreements, especially about wage-contracts.

After an explanation of the laws' content, some of the participants envisaged these as a means to secure their rights. Many of the provisions of the laws, for example those on working hours and on days off work, were far from the reality of some of the 16-17-year-olds. They reacted strongly to descriptions of the laws, finding them absurd. Nevertheless, they saw in some of the provisions an opportunity to realise their rights:

Interviewer: Do I understand correctly that you do not agree with this regulation?

Rannveig: It is just that I don't care about this law (another girl laughs and then agrees with her).

Sara: It is of course that that no one follows these rules. They exist, and you know about them, you know, if you want a longer holiday, or something, otherwise no one gives them a thought.

However, the group interviews reveal that the participants were more concerned about their general work rights than about their special labour market rights as secured by child labour laws. Thus, after a short discussion on child labour laws they frequently steered the discussion toward issues concerning general labour market rights, especially regarding their wages.

\subsection{General labour market rights}

In Iceland the trade unions negotiate with the employers for the wages of workers as young as 14, but notably, the wage rates for those under 18 are lower than for those who have reached adulthood (and lower for 14-years-olds than for 15-year-olds, etc.). As such, wage rates for the age-group are to be found in collectively agreed wage contracts. That said, it is also worth noting that the young people themselves do not take part in the negotiations. Most of the participants were aware of the existence of the wagecontracts for their age-group and some revealed substantial knowledge of their content. For instance, a group of secondary school pupils in a rural town with a surplus supply of jobs in the retail and fast-food sectors pointed out that it was not possible for the town's employers to cheat young workers. They argued that 'probably everyone has been caught in that'; that is, caught in having to confront a cheating employer who had tried to pay under the rate, forgotten to pay into the holiday leave fund (stipulated by Icelandic law), or tried to pay 'average pay'. By average pay they are referring to the employer not paying extra for evening, night and weekend shifts, but instead negotiating an average rate that covers both daytime work on a weekday and the work at other hours. These participants pointed out that they had learnt that it was against the wage contracts to pay average pay and that it was not possible for the town's employers to do so: 
Rannveig: [The employers] try to pay you insanely little per hour when you start working somewhere. Always try to pay you, you know, average pay, or something, but we are fully aware that it doesn't exist.

The very existence of the wage-contracts and the young workers' knowledge of them did not prevent discontent over payment, as the group interviews revealed. Some expressions of dissatisfaction related to formal work in the retail and fast-food sectors, and some centred upon payment not being in accordance with the wage contracts. In several instances, the young workers turned to the relevant trade union for assistance. Interestingly, there were some examples of young workers in the retail and fast-food sectors who were paid according to the wage-contract, but they tried to negotiate a pay raise anyway, although sometimes without success. The stories of the young workers reveal, however, that despite the wage-contracts and available help of the relevant trade union being a possible means of negotiation, the discontented young workers often ended up simply quitting the job.

\subsection{Labour market position}

Young Icelanders consider the position of children and teenagers on the labour market to be weak, even comparable to the labour market position of immigrants:

Páll: When you are a teenager you are ordered to do everything that needs to be done, you know. You are like the Poles in construction work (laughter from one girl). You are just thrown to wherever [the boss] wants to utilise you.

In another interview adult prejudice of young workers was openly discussed:

Interviewer. Do you think that employers view young people differently?

Ester: Yes, yes (her friend agrees in the background), it is also that we are judged, you see, they think that we don't work as much as older people, you know, they are always staring at you, you know, if you are not hurrying up.

Interviewer: You mean the supervisor?

Ester: Yes, you are being prejudged, like you are doing worse work than the older ones, or, you know, are just mucking about.

The lack of power of child and teenage workers and adult prejudice were not only discussed generally but also came to the fore in the young workers' accounts of the 'not nice boss'. Included in the term was the sense of the boss being unfair. One of the accounts of such a 'not nice boss' concerned a supervisor in a workplace mainly staffed by immigrants and teenagers. According to a participant, the boss let the immigrants perform all the easy tasks but was insanely against the kids, and something. And [the 
boss] is always threatening to fire us all'. The young employees feared that the boss would pick some of them and fire them. They had discussed this quite a lot amongst themselves, and if the boss would act as s/he had said s/he would the teenagers were, at the time of the interview, planning to quit the job. This time the intended exit would be at the collective level as all the teenage employees were planning to quit at the same time.

Even though many of the term-time workers had an agreement with their employers about their working hours, in reality the hours were rather flexible. This applied in particular to those working in the retail sector. Sometimes the working week was longer than agreed upon, sometimes shorter. It was common for term-time workers to deploy this flexibility of their work to manage their time, inter alia by monitoring that the time they spent at work did not interfere with their studies. At first sight these accounts might contradict with the above findings of young Icelanders perceiving of themselves as a powerless group on the labour market. A closer look at the data reveals, however, that the power the young term-time workers had to manage their time was restricted. The data shows examples of employers who refused to allow term-time workers to reduce their work during final exams, as well as of term-time workers who simply quit their jobs before their work-load at school peaked, instead of trying to negotiate their working hours with their employers. This deployment of quitting as an option instead of negotiating to work fewer hours adds to the before mentioned deployment of quitting because of a 'not a nice boss' and because of discontent over payment.

\section{Discussions}

On the whole, the findings show an ambiguous picture of the labour market position of workers, aged 13-17, in Iceland. Their general labour market rights are recognised up to a point. Their common participation in paid work, facilitated by the special summer work projects for the age-group organised by the authorities, indicates that their right to employment is recognised. Although they usually do not have a formal work contract, the vast majority of the young workers receive a payslip and there are particular wagecontracts for the age-group, which demonstrates some acknowledgement of their right to decent pay. At the same time, the special labour market rights of the 13-17-years-old workers are marked by violations. Icelandic child labour laws are commonly breached, and the young workers are poorly informed about the laws and unsure of the content. Furthermore, the right to special occupational health and safety protection is violated and work injuries result.

The question arises as to whether preventive measures and safety training of young workers are deficient. More than a fifth of young people in Iceland aged 13-17 have had at least one accident at work, and 5\% of the injuries caused more than one week's absence from work. The percentage of young workers who have been injured at work increases with age, and boys are more prone to work injuries than girls. These findings concur with research findings from other high-income countries, although multivariate research shows that both age and gender are dependent risk factors for young workers' injuries. It is first and foremost the work setting that independently predicts the risk 
(Breslin, Day, et al. 2007). Nonetheless, preventative actions within as well as outside the workplace may not be enough to secure the occupational health and safety (OHS) of young workers. According to studies on young workers' OHS, powerlessness often hinders the young people from voicing their concerns about unsafe work conditions (Breslin, Polzer et al., 2007; Tucker \& Turner 2013).

Our findings confirm that industrial relations do not favour young people. They commonly conceive of their age-group as a powerless labour market group, and even identify a similarity between their own position and the labour market position of Eastern European immigrants. They often deploy the tactic typical of those who lack power of exiting the workplace in difficult situations: if they are not pleased with their payment; if they perceive of their boss as 'not nice'; if their work interferes with their studies or other aspects of their lives, etc.

It is striking that even in an affluent country where young people are encouraged to work, they lack labour market power. It can be inferred that the industrial powerlessness of young people in affluent societies has something to do with the construction of childhood which implies that the main occupation of children and teenagers is education, with the consequence that their participation in the labour market can only be partial (Qvortrup 1995). Ironically, the construction might also facilitate them exiting the labour market in case of discontents as it leads to their basic needs usually being provided for by others. Nevertheless, in light of how commonly children and teenagers in high-income countries undertake paid work and their emphasis on their right to do so (e.g. in Leonard 2004) one must consider how their labour market position could be improved.

Child work researchers doubt whether the current international child labour policy is in the best interests of young people (e.g. Gasson et al. 2014; Leonard 2004; McKechnie \& Hobbs 1999). Gasson et al. (2014) wonder whether other countries should follow the example of New Zealand, one of the few high-income countries which does not stipulate a minimum age for employment. We do not support such deregulation in the spirit of laissez-faire politics. Rather, we argue that the $19^{\text {th }}$ century legislation on child labour was an intrinsic part of the implementation of compulsory education (e.g. in Cunningham 2005), and an important step towards securing the welfare of young people, not the least by securing their right to special occupational health and safety. However, we argue for a revision of the current child labour policy to update it to the $21^{\text {st }}$ century (see criticism of the $19^{\text {th }}$ century Eurocentrism and adultism in the current policy in Dahlén 2007b). In such a reworking it should be recognised that nowadays young people commonly combine school and part-time work and stress their need for money and decent pay (Einarsdóttir 2013; Leonard 2004; Mizen, Pole \& Bolton 2001a). It should also be acknowledged that the current labour market position of young people can jeopardise their occupational health and safety, as well as that young people are competent political agents (Tuukkanen, Kankaanranta \& Wilska 2013). We argue that young people are able to take part in negotiations on child labour policy, as well as on other issues important for their life and well-being. 


\section{Conclusion}

In this article we have explored the general and the special labour market rights of young people in Iceland and how they understand their labour market rights and position. In short, young workers recognise that their special labour market rights are frequently breached, and they do not seem to care too much about these rights. Their interest is in having the right to work for fair pay when it fits their plans. They position themselves at the edge of the labour market, and this uncertain labour market position in turn allows them to quit when confronted with unscrupulous bosses, an excessive workload or a boring work environment.

We conclude that the labour market position of young people is characterised by ambiguity. Firstly, it is ambiguous in the sense that whereas young people's general labour market rights are recognised up to a point, there is still a lack of acknowledgement regarding their special occupational health and safety rights. Secondly, their labour market position is ambiguous in the sense that the modern construction of a work-free childhood simultaneously pushes young people to the edge of the labour market and makes space for them to exit in the case of discontents. Thirdly, the current child labour policy is marked by ambiguity and unclear messages about what is allowed and what is not. Thus, it is important to further examine the labour market position of young workers. One should ask if and how their position jeopardises their wellbeing and safety. Findings from such research should help to improve young people's OHS and be an input into a revision of the existing child labour policy.

\section{Notes}

1 That is, the rights to freedom of expression and thought, to freedom of association, and to free assembly.

2 See also article 7 of the EU Council Directive 94/33/EC and article 62 of the Icelandic Act on Working Environment, Health and Safety in Workplaces.

3 An identical provision is to be found in article 63 of the Icelandic Act on Working Environment, Health and Safety in Workplaces.

4 See identical article 63 in the Icelandic Act on Working Environment, Health and Safety in Workplaces.

5 See an identical provision in article 63 of the Icelandic Act on Working Environment, Health and Safety in Workplaces.

6 Residency in Iceland is commonly divided into two parts: the capital area and the rest - that is the (fishing) towns and rural areas outside the capital.

\section{References}

Act on Working Environment, Health and Safety in Workplaces. (no. 46/1980). With later changes from 15/1986, 61/1990, 7/1996, 52/1997, 83/199, 17/2003, 68/2003, 90/2004, 138/2005, 88/2008.

Aðalsteinsson, G.D. (2006). „Verkföll og verkfallstíðni á íslenskum vinnumarkaði 1976-2004“ [Strikes in Iceland 1976-2004], Stjórnmál og stjórnsýsla 2(2), 175-196.

Barnetson, B. (2013). "Incidence of work and workplace injury among Alberta teens", Just Labour: A Canadian Journal of Work and Society 20.

Breslin, F.C., Day, D., Tompa, E., Irvin, E., Bhattacharyya, S., Clarke, J. and Wang, A. (2007). "Nonagricultural work injuries among youth: A systematic review", American Journal of Preventive Medicine 32(2), 151-162. 
Breslin, F.C., Polzer, J., MacEachen, E., Morrongiello, B. and Shannon, H. (2007). "Workplace injury or 'part of the job'?: Towards a gendered understanding of injuries and complaints among young workers", Social Science \& Medicine 64(4), 782-793.

Christensen, P. and James, A. (2008). Research with Children: Perspectives and Practices (Second Edition). New York \& London: Routledge.

Creswell, J.W. and Clark, V.L.P. (2007). Designing and conducting mixed methods research: Wiley Online Library.

Cunningham, H. (2005). Children \& Childhood in Western Society since 1500 (Second edition). Pearson Longman.

Dahlén, M. (2007a). Children and work in international law. In K. Engwall \& I. Söderlind (Eds.), Children's Work in Everyday Life (pp. 133-150). Stockholm: Institute for Future Studies.

Dahlén, M. (2007b). The Negotible Cbild: The ILO Child Labour Campaign 1919-1973. (PhD dissertation), Uppsala Universitet, Uppsala.

Einarsdóttir, M. (2008). "Reynsluboltar? Um störf og starfsreynslu íslenskra ungmenna" [On the Occupational Experience of Young Icelanders], in Gunnar Dór Jóhannesson and Helga Björnsdóttir (Eds.), Rannsóknir i félagsvísindum IX, (pp. 293-304). Reykjavík: University of Iceland Social Science Research Institute.

Einarsdóttir, M. (2013). "Happy without money of their own? The case of Iceland", in C. Marklund (Ed.), All Well in the Welfare state? Welfare, well-being and the politics of happiness (pp. 103-134). Helsinki: Nordic Centre of Excellence NordWel.

Einarsdóttir, M. (2014). Paid Work of Children and Teenagers in Iceland: Participation andprotection. Unpublished doctoral thesis, University of Iceland: Faculty of Social and Human Sciences.

Einarsdóttir, M., Rafnsdóttir, G.L. and Einarsdóttir, J. (2014). "Vinnuslys 13-17 ára íslenskra ungmenna: Orsakir og alvarleiki" [Work injuries of 13-17-year-old Icelanders: Causes and seriousness], Laknabladid [The Icelandic Medical Journal] 100(11), 587-591.

EU Council Directive 94/33/EC on the protection of young people at work. (no. 31994L0033/1994). (Officical Journal L 216, 20/08/1994 P. 0012-0020).

Eydal, G.B., Rafnsdóttir, G.L. and Einarsdóttir, M. (2009). "Working children in Iceland: Policy and the labour market", Barn 3-4, 187-203.

Garðarsdóttir, Ó. (1997a). "Working children in Urban Iceland 1930 - 1990", in N. de Coninck-Smith, B. Sandin \& E. Schrumpf (Eds.) Industrious Children: Work and Childhood in the Nordic Countries 1850 1990 (pp. 160-185). Odense: Odense University Press.

Garðarsdóttir, Ó. (2009). "Working and going to school: Childhood experiences in post-war Reykjavík", Barn 3-4, 173-185.

Gasson, N.R., Calder, J.E., Diorio, J.A., Smith, A.B. and Stigter, J.R. (2014). "Young people's employment: Protection or participation?” Childhood 1-17. doi: 10.1177/0907568214524456.

Grint, K. (2004). The Sociology of Work: An Introdution. (Second edition). Cambridge, UK: Polity Press.

Grover, S. (2004). "Why won't they listen to us? On giving power and voice to children participating in social research", Childhood: A Global Journal of Child Research 11(1), 81-93.

Guðmundsdóttir, M.L., Sigfússon, J., Kristiánsson, Á.L., Pálsdóttir, H. and Sigfúsdóttir, I.D. (2010). A Comparative Research Among 16 to 19 Years old Students in the Aland Islands, Denmark, The Faroe Islands, Finland, Greenland, Iceland, Norway and Sweden: Icelandic Centre for Social Research and Analysis [Rannsóknir \& greining].

Hanson, K. and Vandaele, A. (2003). "Working children and international labour law: A critical analysis", The International Journal of Children's Rights 11, 73-146.

Hendrick, H. (1997). "Constructions and reconstructions of British childhood: An interpretative survey, 1800 to the present", in A. James \& A. Prout (Eds.), Constructing and Reconstructing Childhood: Contemporary Issues in the Sociological Study of Childhood (pp. 34 - 62). London \& Philadelphia: RoutledgeFalmer.

Hill, M. (2006). "Children's voices on ways of having a voice", Childhood 13(1), 69-89. doi: $10.1177 / 0907568206059972$. 
Howieson, C., McKechnie, J. and Semple, S. (2006). The Nature and Implications of the Part-time Employment of Secondary Schools Pupils. Edinburgh: Scottish Executive Social Research, The Department of Enterprise, Transport and Lifelong Learning.

ILO Minimum Age Convention. (no. 138/1973).

James, A., Jenks, C. and Prout, A. (1998). Theorizing Childhood. Polity Press.

Johnson, R.B. and Onwuegbuzie, A.J. (2004). "Mixed methods research: A research paradigm whose time has come", Educational Researcher 33(7), 14-26. doi: 10.3102/0013189x033007014.

Kines, P., Framke, E., Salmi, A. and Bengtsen, E. (2013). Young workers' occupational safety and health riskes in the Nordic countries. Copenhagen: Nordic Council of Minesters, TemaNord 2013:569.

Leonard, M. (2004). "Children's views on children's right to work", Childhood: A Global Journal of Child Research 11(1), 45-61.

Liebel, M. (2004). A Will of Their Own: Cross-Cultural Perspectives on Working Children. London, New York: Zed Books.

Mayall, B. (2000). "Conversations with children: Working with generational issues", in P. Christensen and A. James (Eds.), Research with Children: Perspectives and Practices (pp. 120-135). London and New York: Falmer Press.

McDonald, P., Bailey, J., Price, R. and Pini, B. (2012). "School-aged workers: Industrial citizens in waiting?" Journal of Sociology 1-16. doi: 10.1177/1440783312458008.

McKechnie, J. and Hobbs, S. (1999). "Child labour: The view from the North", Childhood: A Global Journal of Child Research, 06(01), 89-100.

Mizen, P., Pole, C. and Bolton, A. (2001a). "Why be a school age worker?”, in P. Mizen, C. Pole \& A. Bolton (Eds.), Hidden Hands: International Perspectives on Children's Work and Labour (pp. 37-54). London: RoutledgeFalmer.

Mizen, P., Pole, C. and Bolton, A. (Eds.). (2001b). Hidden Hands: International Perspectives on Children's Work and Labour. London: RoutledgeFalmer.

Mortimer, J.T. (2003). Working and Growing up in America. Cambridge, Massachusetts: Harvard University Press.

Myrstad, G. (1999). "What Can Trade Unions Do to Combat Child Labour?”, Childhood 6(1), 75-88. doi: $10.1177 / 0907568299006001006$.

Ólafsson, S. (2012). "Inngangur: Lífskjörin 1988 og 2008” [Introduction: The Icelandic standard of living 1988 and 2008], in G.B. Eydal \& S. Ólafsson (Eds.), Dróun velferdarinnar 1988-2008 (pp. 9-28). Reykjavík: Félagsvísindastofun Háskóla Íslands.

Pálsdóttir, K.P. (2012). Care, Learning and Leisure: The Organisational Identity of After-School Centres for Six-to Nine-Year Old Cbildren in Reykjavik. (Unpublished PhD dissertation), University of Iceland, School of Education.

Price, R. and McDonald, P. (Eds.). (2011). Young People and Work. Ashgate Publishing.

Punch, S. (2002). "Interviewing strategies with young people: The 'secret box', stimulus material and task-based activities”, Children \& Society 16(1), 45-56. doi: 10.1002/chi.685.

Qvortrup, J. (1995). "From useful to useful: The historical continuity of children's constructive participation", Sociological Studies of Children 7, 49-79.

Rafnsdóttir, G. L. (1999). Barn- og ungdomsarbete i Norden. Nord 1999:23.

Runyan, C.W., Schulman, M., Dal Santo, J., Bowling, J.M., Agans, R. and Ta, M. (2007). "Work-related hazards and workplace safety of US adolescents employed in the retail and service sectors", Pediatrics, 119(3), 526-534. doi: 10.1542/peds.2006-2009.

Stefánsson, K.H. (2012). "Umfang vinnunar í lífi Íslendinga, 1991-2008" [The extent of work in Iceland, 1991-2008], in G.B. Eydal \& S. Ólafsson (Eds.), Dróun velferóarinnar 1988-2008 (pp. 89-106). Reykjavík: Félagsvísindastofun Háskóla Íslands.

Tucker, S. and Turner, N. (2013). "Waiting for safety: Responses by young Canadian workers to unsafe work”, Journal of Safety Research 45(0), 103-110. doi: http://dx.doi.org/10.1016/j.jsr.2013.01.006. 
Tuukkanen, T., Kankaanranta, M. and Wilska, T.A. (2013). "Children's life world as a perspective on their citizenship: The case of the Finnish Children's Parliament", Childhood 20(1), 131-147. doi: $10.1177 / 0907568212451472$.

Woodhead, M. (1999). "Combatting child labour: Listen to what the children say", Childhood: A Global Journal of Cbild Research 06(01), 27-50.

Zakocs, R.C., Runyan, C.W., Schulman, M.D., Dunn, K.A. and Evensen, C.T. (1998). "Improving safety for teens working in the retail trade sector: Opportunities and obstacles", American Journal of Industrial Medicine 34, 342-350. 
